\title{
Analysis of Productivity Improvement in Production Process Using the Single Minutes Exchange of Dies (SMED) Method
}

\author{
Sakti Aji Lesmana \\ Department of Industrial Engineering \\ Faculty of Engineering, University of Mercu Buana \\ Jl. Raya Meruya Selatan, Kembangan, Jakarta 11650 \\ Indonesia
}

\begin{abstract}
$P T X$ is a manufacturing company engaged in the manufacture of automotive components. This company is a joint venture between an Indonesian company and a Japanese company. The company's main products are grouped into Drive Train, Engine Related Part, and Body Related Part. As a multi-national company, the company's ability to maintain efficiency is very important. Of course, to keep the market competitive and to win the competition. One of the efficiencies that must be done is to reduce unproductive time, namely time that does not produce products. This research will focus more on the timing of the model changeover. Product XZ is one of the superior products of PT. X, but from the data obtained, this production line only has an effective time of $73 \%$ of the total working hours. This is due to the high time to change the model on the work track. The time to change the model reaches 25.75 minutes. So that the maximum production capacity is 5,968 pcs / day. To solve this problem, the Single Minutes Exchange of Dies (SMED) method is used. By implementing the 7 steps of SMED and supported by problem analysis using Pareto diagrams and why-why analysis, improvement in Production time productivity is increased by $25.3 \%$, whereas, the productivity of the production line shows improvement from 6.94 parts/minute to 8.70 parts/minute.
\end{abstract}

Key Words: Single Minutes Exchange of Dies (SMED), Efficiency, Production capacity, Productivity.

\section{INTRODUCTION}

PT X is a manufacturing company that produces Engine Related Parts, Body Related Parts, and Drive Trains. One of the flagship products of this company is the XZ product. Along with the development of the automotive industry, the demand for these products also increases. This increase in demand must be responded to positively, namely by continuously increasing process productivity. With the industry concept currently in effect, namely the price is determined by the customer, it is difficult to survive if productivity is not continuously improved.

In the world of the manufacturing industry, waste is a phenomenon that is often experienced by companies, whether it occurs naturally or by human factors during production. Waste that occurs can result in losses to the company, one example of losses that can be caused due to waste is the product completion time which is longer than what was planned (Wijayanto et al., 2015)

So far, in the process of increasing productivity, the company only focuses on work speed (cycle time). Up to a point, these business actors will find it difficult to speed up cycle time. Therefore, other alternatives are needed to increase the productivity of a production line. This is because the factors that affect productivity are not only cycle time, but also the effective time available to carry out the production process. One that causes the effective time to be reduced is due to the long set up time which can be seen with the reduced production time which is reflected by the reduced production output when the model changes.

\section{LITERATURE SURVEY}

One of the methods used to reduce setup time is Single Minutes Exchange of Dies (SMED). The SMED concept, which divides setup work into internal and external activities, is usually the subject of discussion in research journals related to improving set up time. Furthermore, from the separation of these activities, it is very important to make improvements so that it will be able to minimize time on internal activities, thereby minimizing machine downtime.

Change over time is defined as the length of time it takes to make product changes and machine set-up starting from the last product finished production until the first new product starts to be produced again. Change over time is a form of waste or waste contained in lean manufacturing because it does not provide value added to a product (non-value added) and also causes the production process to stagnate. 
To apply the SMED method to a production line, there are several steps that can be followed, so that the decrease in set up time can be maximized. So the impact of decreasing set up time can be significant. The following are the stages of implementing SMED according to Singo (1985).
a. Separating Internal and External activities
b. Standardization of External Activities
c. Move Internal Activities to External Activities
d. Improve Internal Activities
e. Improve External Activities
f. Set Up Mechanization
g. Remove Change Over

\section{OBJECTIVE OF THE STUDY}

The main objective of this study based on the background and problem formulation previously mentioned was to find out the time required to perform an automatic model changeover accompanied by a jig change over as well as a machine reset which required sufficient time to make several product units. After knowing the time required for the changeover, it will identify the factors that affect the productivity of the XZ product production process. By knowing the factors that affect productivity, it is hoped that further solutions and proposals can be found to increase productivity consistently and measurably.

\section{RESEARCH METHODOLOGY}

SMED was developed by Toyota and first introduced by Shigeo Shingo. The steps in improvement using the SMED method consist of 4 stages:

- Stage 1 : Record all activities in the production process. The initial stage of SMED is to record and collect all activities in the production process of XZ regardless of whether these activities are included in internal or external activities.

- Stage 2 : Separate internal and external activities. To facilitate the implementation of SMED, internal and external activities need to be grouped into 2 separate activity groups between external and internal activities. The total production process time only calculates internal activities, because external activities can be carried out when the line is stopped, for example during the stock taking process which is carried out regularly at the end of the month.

- Stage 3 : Converting internal activities into external activities. This is the most important stage of SMED, which is converting internal activities into external activities so that it is expected that the total production process time will be reduced. In the production process, this is done by using Pareto diagram tools so that it is easier to find the largest and has the potential to make a large enough increase in cycle time.

- Stage 4 : Streamlining all activities. This stage is an improvement stage in order to reduce all activities carried out in the production process of $\mathrm{XZ}$ products, for example reducing unnecessary movements such as picking up fallen bolts, body twisting movements, and unnecessary steps taken during the process. The method of analysis in research uses a combination of several methods as follows:

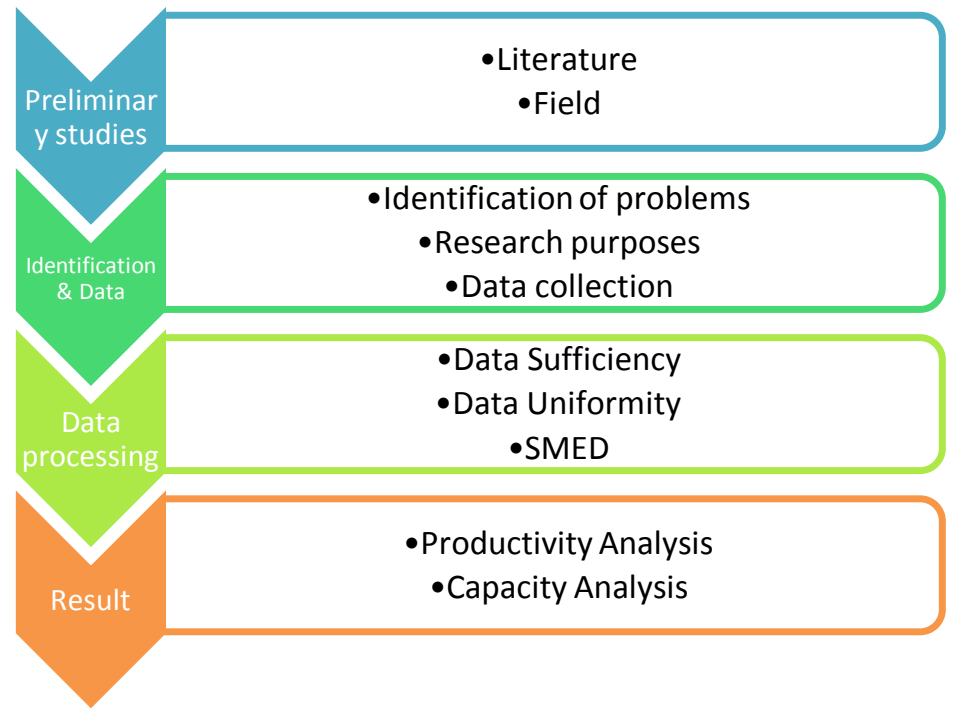

Figure 1 Research Stages 


\section{RESULT AND DISCUSSION}

Based on the model changeover time for each die and robot as shown in Table 5.3. To clarify the total time of the model change over process, the authors make a summary table of all model changeover times. The total time required to change the model on the $\mathrm{XZ}$ product line is as follows.

Table 1. Dies/mold change over time

\begin{tabular}{|c|c|c|c|c|}
\hline \multirow{2}{*}{ No } & \multirow{2}{*}{ Activity } & \multicolumn{3}{|c|}{ Time (Second) } \\
\hline & & Manual & Automatic & Walk \\
\hline \multicolumn{5}{|c|}{ Dies Changeover } \\
\hline 1 & Dies Changeover Machine 1 & 263 & & 5 \\
\hline 2 & Dies Changeover Machine 2 & 263 & & \\
\hline \multicolumn{5}{|c|}{ Setting Loader } \\
\hline 3 & $\begin{array}{l}\text { Setting Loader (Done by } 1^{\text {st }} \text { Operator together } \\
\text { with dies change over } \& \text { Finger Idle stage } \\
\text { Changeover) }\end{array}$ & 615 & & \\
\hline \multicolumn{5}{|c|}{ Finger \& Idle Stage Changeover } \\
\hline 4 & Robot 1 Finger \& Idle Stage Changeover & 422 & & 5 \\
\hline 5 & Robot 2 Finger \& Idle Stage Changeover & 422 & & \\
\hline \multicolumn{5}{|c|}{ Production Equipment Setting } \\
\hline 6 & Shutter Scarp Installation & 10 & & 15 \\
\hline 7 & Shutter Scarp Installation & 10 & & 15 \\
\hline 8 & Shutter Scarp Installation & 10 & & 15 \\
\hline \multicolumn{5}{|c|}{ Production Set Up } \\
\hline 9 & Product Set Up & 90 & & \\
\hline \multicolumn{2}{|r|}{ Total } & 1490 & & 55 \\
\hline
\end{tabular}

Observing Table 1, it is known that the total time required to change the model is 1,545 seconds or 25.75 minutes, consisting of 1,490 seconds of manual work and 55 seconds of travel. It should be noted that the loader model changeover time (yellow in Table 5.4) is carried out simultaneously with activities number 1, 2, 4, and 5.

\section{SMED $\rightarrow$ Expand the SMED}

\section{Separation of Internal and External Activities}

There are 2 sub-activities of changing models, namely changing dies and also changing robot equipment. All activities are internal activities, this is because turnover activities can only be carried out if the machine is not in production. Because the activity carried out is to replace the production equipment, in this case the dies/molds. Like the process of changing the dies/mold model, the changeover of robot equipment can only be done when the machine is not operating. Therefore, all processes are internal activities. With the description above, it can be seen that all model changeover processes are internal activities, so to reduce set up time, improvements must be made to the work process. 
International Journal of Engineering Research and Advanced Technology, Vol. 8, No1, January -2022

Table 2. Grouping of dies equipment and robot replacement activities

\begin{tabular}{|c|c|c|c|}
\hline \multirow{2}{*}{ No } & \multirow{2}{*}{ Alantas } & \multicolumn{2}{|c|}{ Jens Aktaths } \\
\hline & & Intheral & Ekstennal \\
\hline$t$ & $\begin{array}{l}\text { Puar suatch } A \text { H Master \& Openatian Select ke posii } \\
\text { DNCHING }\end{array}$ & 0 & - \\
\hline 2 & Naùlkan Dee Hevigut & 0 & . \\
\hline 3 & Trumian RAM ke posis TMB & 0 & . \\
\hline 4 & Lequs pengenciabs da bawah serta depan \& bebare & 0 & - \\
\hline 5 & Naukan RAM pada possi IMLA & 0 & - \\
\hline 6 & Nablikn die (fiter finclamp lower clawp) & 0 & * \\
\hline 7 & Dorong \& keharkan des afer process ke kerea dandont & 0 & . \\
\hline 8 & $\begin{array}{l}\text { Ketarkan dies pada ketet dandori setebh proses } \\
\text { kenndan puth dengan dies yang akan proses }\end{array}$ & 0 & $=$ \\
\hline 9 & Tark dies ke base arin (bkikan proses centerting dies) & 0 & - \\
\hline 10 & Tunakan die hôter & 0 & - \\
\hline 11 & Nalkan DH mrin ( + Somdari DH dies) & 0 & + \\
\hline 12 & Tnnakan RAM ke poisi TMB & 0 & . \\
\hline 13 & Lepas penaraciatas das bawah sert depan $\&$ behbare & o & $=$ \\
\hline 14 & Nalkan RAM pata posei DMA & 0 & . \\
\hline 15 & $\begin{array}{l}\text { Setring thes dgan can menik turekan des } 3 \text { kak } \\
\text { (possikan TM(A) }\end{array}$ & o & - \\
\hline 16 & Seting DH nesis senai DH dies & 0 & $=$ \\
\hline 17 & Seting anin ke posisi trangfor itue & 0 & + \\
\hline
\end{tabular}

\begin{tabular}{|c|c|c|c|}
\hline \multirow{2}{*}{ No } & \multirow{2}{*}{ Aktrivitas } & \multicolumn{2}{|c|}{ Jenis Alktivitas } \\
\hline & & Internal & Ekstemal \\
\hline \multirow[t]{2}{*}{1} & Unlock finger (tekan pada panel utama) & $\mathrm{O}$ & - \\
\hline & Lepas Finger 1 & & \\
\hline 2 & Lepas konektor finger & $\mathrm{O}$ & - \\
\hline 3 & Lepas finger & 0 & - \\
\hline \multirow[t]{2}{*}{4} & Letakkan finger pada tempat sementara & $\mathrm{O}$ & - \\
\hline & Idle Stage & 0 & - \\
\hline 5 & Lepas idle stage & $\mathrm{O}$ & - \\
\hline \multirow[t]{2}{*}{6} & Letakkan idle stage pada tempat sementara & $\mathrm{O}$ & - \\
\hline & Lepas Finger 2 & & \\
\hline 7 & Lepas konektor finger & 0 & - \\
\hline 8 & Lepas finger & $\mathrm{O}$ & - \\
\hline \multirow[t]{2}{*}{9} & Letakkan finger pada tempat sementara & 0 & - \\
\hline & Open Lifter Storage & $\mathrm{O}$ & - \\
\hline 10 & Tekan tombol open lifter storage & 0 & - \\
\hline 11 & Tunggu fffer storage terbuka + proses storage tertutup & $\mathrm{O}$ & - \\
\hline 12 & Letakkan finger (2 pcs) \& idle stage (1 pcs) pada storage & $\mathrm{O}$ & - \\
\hline 13 & Anbil finger (2 pcs) \& idle stage (1 pcs) pada storage letakkan & 0 & - \\
\hline \multirow[t]{2}{*}{14} & pada tempat sementara & $\mathrm{O}$ & - \\
\hline & Pasang Finger 1 & & \\
\hline 15 & Ambil finger dari tempat sementara & $\mathrm{O}$ & - \\
\hline 16 & Pasang finger & $\mathrm{O}$ & - \\
\hline \multirow[t]{2}{*}{17} & Pasang konektor kabel & $\mathrm{O}$ & - \\
\hline & Idle Stage & & \\
\hline 18 & Ambil idle stage dari tempat sementera & 0 & - \\
\hline \multirow[t]{2}{*}{19} & Pasang idle stage & $\mathrm{O}$ & - \\
\hline & Lepas Finger 2 & & \\
\hline 20 & Anbil finger dari tempat sementara & 0 & - \\
\hline 21 & Pasang finger & 0 & - \\
\hline 22 & Pasang konektor kabel & 0 & - \\
\hline 23 & Lock finger & $\mathrm{O}$ & - \\
\hline
\end{tabular}

\section{Standardization of External Activities}

All recorded activities are internal activities according to the table previously created by the Engineering team. This is important to ensure that the time allotted for changing the model is actually on target. That is only time caused by internal activity.

\section{Move Internal Activities To External Activities}

In accordance with the results of previous observations, it was found that all activities must be carried out when the machine is not operating. And if it is done when the engine is operating, it will not be able to do the replacement. Because all the equipment is the main equipment and in a moving position.

\section{Improve Internal Activities}

a. Dies Change Over Time Improvements

Table 3. Dies Set Up Time Improvements

\begin{tabular}{|c|c|c|c|}
\hline No. & Issues & Root Causes & Improvements \\
\hline \multirow[t]{2}{*}{1.} & \multirow{2}{*}{$\begin{array}{l}\text { Took too much time to insert and } \\
\text { remove dies }\end{array}$} & $\begin{array}{l}\text { Cable pit is not strong } \\
\text { enough to withstand } \\
\text { the weight of the die } \\
\text { when there is a } \\
\text { changeover of model }\end{array}$ & $\begin{array}{l}\text { Adding a frame to the } \\
\text { cable pit, so that when } \\
\text { there is a changeover } \\
\text { model is not going to } \\
\text { bend }\end{array}$ \\
\hline & & $\begin{array}{l}\text { No marking of exact } \\
\text { dies position }\end{array}$ & $\begin{array}{l}\text { Mark position of dies } \\
\text { proper placement on } \\
\text { dandori table (change } \\
\text { model) }\end{array}$ \\
\hline 2. & Took too much time to centered the dies & $\begin{array}{l}\text { Operator must remove } \\
\text { and install stopper } \\
\text { dies manually }\end{array}$ & $\begin{array}{l}\text { Make a stopper that } \\
\text { can open and close } \\
\text { automatically when } \\
\text { the position is center }\end{array}$ \\
\hline
\end{tabular}




\begin{tabular}{|l|l|l|l|}
\hline 3. & $\begin{array}{l}\text { Waktu untuk memasang dan melepas } \\
\text { pengunci dies lama }\end{array}$ & $\begin{array}{l}\text { The lock is bolted and } \\
\text { the operator must } \\
\text { enter the machine to } \\
\text { install and remove } \\
\text { manually }\end{array}$ & $\begin{array}{l}\text { Using a semi- } \\
\text { automatic lock to } \\
\text { make the removal and } \\
\text { installation of lock } \\
\text { easier }\end{array}$ \\
\hline
\end{tabular}

b. Robot Model Change Over Time Improvement

- Changed the idle stage design which initially used a stopper from the outside of the part, replaced with 2 pins which were set the same for each model. So that the initial process must replace the idle stage because the outer stopper is different, it will be replaced with a new idle stage that has 2 pins that neither the position nor the components need to be changed.

- Changed the material lifting position on all fingers, so that it can be used to lift all model parts. With this step, it can eliminate finger changing times and also the need for fingers. Previously, 36 fingers were needed to produce all model parts, while after improvements, only 17 fingers were needed for all model parts.

c. Model Loader Change Over Time Improvement

In the total improvement time of model changeover, there is a very large set up time reaching 615 seconds, namely in the setup loader process. To overcome this problem, improvements were made by making a new loader that was equipped with position markings and pin holes for each model, so that the operator would be faster in setting up the loader.

\section{Remove Change Over}

This is very unlikely to be done, because the production process with a press machine definitely requires time to stop if you are going to replace the dies. Because it would be impossible to remove the dies while the engine is operating. In this case, what can be done is to minimize machine downtime.

\section{Evaluation of Set Up Time Decrease}

Please note, that in the improvement process with SMED that has been carried out, there are 5 improvements made, namely:

a. The process of removing the upper \& lower and front \& rear clamp

b. The process of removing the dies on the dandori carriage after the process then replaces it with the dies before the process

c. The process of pulling the dies to the base of the machine (do the centering dies process)

d. The process of installing the upper \& lower and front \& rear clamp

e. The setup loader process

f. Robot set up process that consists of the idle stage and finger change

\section{Set Up Time After Improvement}

After conducting a time study as discussed above, a new set up time is obtained for each process that undergoes changes. By getting a new time, it will automatically change the need for set up time in the process of changing dies, changing robot equipment, and setting loaders.

Table 4. Data of Set Up Dies After Improvement

\begin{tabular}{|c|l|c|c|c|}
\hline \multirow{2}{*}{ No. } & \multicolumn{1}{|c|}{ Activities } & \multicolumn{2}{c|}{ Time } \\
\cline { 3 - 5 } & & $\begin{array}{c}\text { Manual } \\
\text { Process }\end{array}$ & $\begin{array}{c}\text { Automatic } \\
\text { Process }\end{array}$ & \multirow{2}{*}{ Run } \\
\hline 1 & Turn the AH Master switch \& select operation to INCHING & 3.0 & & \\
\hline 2 & Elevate die height & 10.0 & & \\
\hline 3 & Lower RAM to TMB & 5.0 & & \\
\hline 4 & Remove the upper \& lower and front \& rear clamp & 8.0 & & \\
\hline 5 & Elevate the RAM to TMA & 5.0 & & \\
\hline 6 & Elevate the die lifter (unclamp lower clamp) & 8.0 & & \\
\hline 7 & Push and remove the after-process dies to dandori carriage & 4.0 & & \\
\hline 8 & $\begin{array}{l}\text { Remove the dies on the dandori carriage after the process } \\
\text { then replace it with the dies before the process }\end{array}$ & 20.0 & & \\
\hline 9 & $\begin{array}{l}\text { Pull the dies to the base of the machine (do the centering dies } \\
\text { process) }\end{array}$ & 5.0 & & \\
\hline 10 & Lower die lifter & 3.0 & & \\
\hline 11 & Elevate DH machine (+ 5 mm from DH dies ) & 8.0 & & \\
\hline
\end{tabular}


International Journal of Engineering Research and Advanced Technology, Vol. 8, No1, January -2022

\begin{tabular}{|c|l|c|c|c|}
\hline 12 & Lower RAM to TMB & 5.0 & & \\
\hline 13 & Install the upper \& lower and front \& rear clamp & 10.0 & & \\
\hline 14 & Elevate RAM to TMA & 5.0 & & \\
\hline 15 & $\begin{array}{l}\text { Set dies by elevating and lowering dies 3 times (positioned } \\
\text { TMA) }\end{array}$ & 5.0 & & \\
\hline 16 & Setting DH machine based on DH dies & 7.0 & & \\
\hline 17 & Setting machine to transfer line & 7.0 & & \\
\hline \multicolumn{2}{|c|}{ Total Time } & 118.0 & & \\
\hline
\end{tabular}

Table 5. Set Up Time Data After Improvement

\begin{tabular}{|c|l|c|c|c|}
\hline \multirow{2}{*}{ No. } & \multicolumn{1}{|c|}{ Activities } & \multicolumn{2}{c|}{ Time } \\
\cline { 3 - 5 } & & $\begin{array}{c}\text { Manual } \\
\text { Process }\end{array}$ & $\begin{array}{c}\text { Automatic } \\
\text { Process }\end{array}$ & Run \\
\hline & Dies Change Over & & & \\
\hline 1 & Machine 1 dies change over & 118.0 & & 5.0 \\
\hline 2 & Machine 2 dies change over & 118.0 & & \\
\hline & & & & \\
\hline & Loader Setting & & & \\
\hline 3 & $\begin{array}{l}\text { Loader Setting (by 1 MP along with the dies and finger idle } \\
\text { stage change over) }\end{array}$ & 435.0 & & \\
\hline & \multicolumn{1}{|c|}{ Total Time } & & & \\
\hline & Production Equipment Setting & & & \\
\hline 4 & Shutter scrap installment & 10.0 & & 15.0 \\
\hline 5 & Shutter scrap installment & 10.0 & & 15.0 \\
\hline 6 & Shutter scrap installment & 10.0 & & 15.0 \\
\hline & \multicolumn{1}{|c|}{} & & \\
\hline & Production Set Up & 90.0 & & \\
\hline 7 & Production Set Up & 435.0 & 0.0 & 50.0 \\
\hline & \multicolumn{2}{|c|}{} & & \\
\hline
\end{tabular}

Table 6. Comparison of Improvement Impact

\begin{tabular}{|c|c|c|c|c|c|c|}
\hline No. & Comparison Item & Unit & Before & After & $\begin{array}{c}\text { Difference } \\
(\%)\end{array}$ & Result \\
\hline 1 & Model Change Over Time & Second & 1545 & 485 & $-68.6 \%$ & Reduce \\
\hline 2 & Net Time for Production & Hour/day & 10.5 & 13.12 & $25.3 \%$ & Increase \\
\hline 3 & Kapasitas Produksi & Pcs/day & 5968 & 7479 & $25.3 \%$ & Increase \\
\hline 4 & Produktivitas Waktu Kerja & Pcs/minute & 6.94 & 8.7 & $25.0 \%$ & Increase \\
\hline
\end{tabular}

From the data above, it is known that the condition of the production trajectory is improving, this is indicated by a decrease in the model change over time, which means a decrease in unproductive time in one day. This has a direct impact on the increase in net time that can be used to carry out production by $25.3 \%$.

By decreasing ineffective time and also increasing the time available for production, it can increase production capacity in one day. The increase in capacity that occurred was $25.3 \%$ from the condition before the improvement. Production capacity increased from 5,968 pcs per day to 7,873 pcs per day.

In addition, for production line work productivity, from the calculation results it is known that the use of work capacity before improvement is $95.7 \%$. Or in 1 minute it only produces 6.94 pcs. Meanwhile, after the improvement, the productivity of the work line becomes $8.7 \mathrm{pcs} /$ minute, or only uses $76.4 \%$ of the production capacity.

\section{CONCLUSION}

After improving the model changeover time using the Single Minutes Exchange of Dies (SMED) method, it was found that the efficiency of the model changeover time was $68.6 \%$, from 1,545 seconds to 485 seconds. With a decrease in the value of changing the model time obtained by $68.6 \%$, it results in increasing the effective time to carry out production and also production capacity 
by $25.3 \%$. Before the improvement, the production capacity of 5,968 pcs/day increased to 7,479 pcs/day. Production time productivity, increased by $25.3 \%$ where the productivity of the production line changed from $6.94 \mathrm{pcs} / \mathrm{minute}$ to $8.70 \mathrm{pcs} / \mathrm{minute}$.

\section{REFERENCES}

1. Agung, D., \& Hasbullah, H. (2019). Reducing the Product Changeover Time Using Smed \& 5S Methods in the Injection Molding Industry. Synergy, 23(3), 199. https://doi.org/10.22441/sinergi.2019.3.004

2. Arvianto, A., \& Arista, R. (2011). Proposed Improvement of Operation Point Sheet on Aida 1100 Feeder Machine Using the SMED Method. Jati Undip, VI(2), 125-136. https://ejournal.undip.ac.id/index.php/jgti/article/view/2168

3. Da Silva, I. B., \& Godinho Filho, M. (2019). Single-minute exchange of die (SMED): a state-of-the-art literature review. International Journal of Advanced Manufacturing Technology, (Vol. 102, Issues 9-12, pp. 4289-4307). Springers London. https://doi.org/10.1007/s00170-019-03484-w

4. Hidayat, D. F., Hardono, J., \& Santoso, T. M. (2020). Improvement of Set-up Time Using Single Minute Exchange Die (SMED) Method at PT. MOBILE PHONE. Journal of Industrial Manufacturing, 5(1), 18-22. http://jurnal.umt.ac.id/index.php/jim/article/view/2431

5. Karam, A. A., Liviu, M., Cristina, V., \& Radu, H. (2018). The contribution of lean manufacturing tools to changeover time decreases in the pharmaceutical industry. A SMED project. Procedia Manufacturing, $22,886-892$. https://doi.org/10.1016/j.promfg.2018.03.125

6. Heriansyah, Endang, and Zulfa F. Ikatrinasari. Improving Workers Performance on the 600 Ton Fukui Machine Using Exchange of Dies (SMED) Method. Researches and Applications of Industrial System and, vol. 11, no. 2, 2017.

7. Palanisamy, S., \& Siddiqui, S. (2013). Changeover Time Reduction and Productivity Improvement by Integrating Conventional SMED Method with Implementation of MES for Better Production Planning and Control Corresponding Author. International Journal of Innovative Research in Science, Engineering and Technology, 2(12), 7961-7974. Www.izirset.com

8. Saputra, R., Arianto, H., \& Irianti, L. (2016). Proposed Minimizing Set-Up Time Using Single Minute Exchange Die (SMED) Method at Company X. Ejurnal.Itenas.Ac.Id, 4(2), 206-218. http://ejurnal.itenas.ac.id/index.php/ rekaintegra/article/view/1102

9. Setyawan, L. (2018). Increasing the Capacity of the Copper Drawing Frame Using the Smed Method in the Cable Industry in Tangerang [Mercu Buana University]. https://repository.mercubuana.ac.id/45031/

10. Shingo, S. (2019). A Revolution in Manufacturing: The SMED System. In A Revolution in Manufacturing: The SMED System. Routledge. https://doi.org/10.4324/9781315136479

11. Sudargo, K. W., \& Felicia. (2015). Reduction of Changeover Time with SMED Method at PT. Schneider Electric Manufacturing Batam-Plant Electro Mechanic. In Reducing Changeover Time with the SMED Method at PT. SEMB-PEM/ Jurnal Titra (Vol. 3, Issue 2). http://publication.petra.ac.id/index.php/teknik-industri/article/view/3438

12. Sudarmaji, H., \& Sidiq, R. (2019). Reducing Dandori Process Time With Single Minute Exchange Of Die Method In PT ASKI Production Area. Technologic.Polman.Astra.Ac.Id, 10(1), 1-10. https://technologic.polman.astra.ac.id/index.php/ firstjournal/article/view/252 